\title{
IAMJ
}

INTERNATIONAL AYURVEDIC MEDICAL JOURNAL

\section{A REVIEW OF PANCHAKARMA THERAPIES WITH RESPECT TO BALA (IMMUNITY) FOR PREVENTION AND MANAGEMENT OF COVID-19}

\author{
Vedpathak $S^{1}$, Bapat $V^{2}$, Tanwar $V^{3}$ \\ ${ }^{1}$ Professor and HOD, PG Department of Panchakarma, NIA, Jaipur, Rajasthan, India \\ ${ }^{2}$ Panchakarma Vaidya, NIA, Jaipur, Rajasthan, India \\ ${ }^{3}$ Panchakarma Vaidya, NIA, Jaipur, Rajasthan, India
}

Corresponding Author: drsurendravedpathak50@gmail.com

\section{https://doi.org/10.46607/iamj3408112020}

(Published online: November 2020)

Open Access

(C) International Ayurvedic Medical Journal, India 2020

Article Received: 31/10/2020 - Peer Reviewed: 06/11/2020 - Accepted for Publication: 08/11/2020

(D) Check for updates

\begin{abstract}
Introduction: Worldwide prevalence rate of COVID-19 is increasing day wise, and estimated at $6.6 \%$ in the Indian population in August 2020, the curable medicine and immunization for COVID-19 is not available yet. The disease COVID-19 can be compared with Janapadodhansa Vyadhi (Epidemic) mentioned in Ayurveda. Panchakarma therapies are advised in Janapadodhansa Vyadhi. Virus is very prominent, and it is the common cause mentioned in both. The Ayurved fraternity and people have fear about Panchakarma therapies in the COVID-19 era. Aim: need of current situation is to find applicability effectiveness of Panchakarma therapies. Methodology: By critical literary search of Classical Ayurvedic texts, electronic media, PubMed, indexed Journal, Google scholar is carried out and observations were recorded. Observation and Results: Panchakarma helps to increase Bala (Immunity) and improves immunomodulation effect of Rasayana (Rejuvenation) medicine. Fever, Headache, Common cold, Cough, Dyspnea, these are common symptoms found in COVID-19 and Panchakarma therapies are indicated in the same. Conclusion: Panchakarma Therapies, are independently advocated for improvement of Bala (Immunity) and as a preoperative measure for improving immunomodulation property of Rasayana (Rejuvenation) medicines. These principles of Panchakarma Therapies can be applied in prevention and treatment of COVID- 19 disease.
\end{abstract}

Keywords Ayurveda, Bala, COVID-19, Janapadopdhansa, Immunity, Immunomodulator, Panchakarma, Rasayana, Rejuvenation. 


\section{INTRODUCTION}

In this era, large number of people are suffering from the disease COVID-19, second serological survey study conducted by Indian Council of Medical Research (ICMR), Delhi, India, showed that, one in 15 people aged 10 years and above were exposed to COVID-19 by August 2020 with prevalence of the infection estimated at $6.6 \%$ in the population, adults at $7.1 \%$, urban slums at $15.6 \%$, non-slums and rural areas $4.4 \%$ in population ${ }^{1}$. CoVs (Corona Virus) are positivestranded RNA virus with a crown-like appearance (Coronam is the Latin term for crown) due to the presence of spike glycoproteins on the envelope. In 2020 the W.H.O. announced that the disease caused by this new CoV was a 'COVID-19', which is the acronym of 'Coronavirus Disease 2019'. At present no medicine is available to cure and vaccinate for immunization of COVID-19 and it's a well-known fact. We can co-relate the COVID-19 disease with Janapadodhansa Vyadhi (Epidemic) described in Ayurveda, because symptoms of both are very similar. Panchakarma are more useful for patients who suffer from such kind of diseases, that they find procedures and death on similar level. In such conditions Panchavidha Karma namely Vamana (Emesis), Virechana (Purgation), Basti (Drug enema), Nasya (Errhine) and Raktamokshana (Bloodletting) said to be beneficial. Panchakarma therapies are advised in the treatment of Janapadodhansa Vyadhi (Epidemic), seems to be neglected in overwhelming fear of COVID-19 pandemic. If we neglect classical treatment protocol and expect result from Ayurveda treatment then it could be the forbidden fruit. Present literary study is aimed to find efficacy of Panchakarma on the basis of Bala (immunity) and improving immunomodulation effect of Rasayana (Rejuvenation) medicines for prevention and treatment of COVID-19 disease.

\section{Methods}

Literary study deals with, Step I- To study different aspects of COVID-19 disease and its probable co-relation with Janapadopdhansa Vyadhi (Epidemic) mentioned in Ayurveda.
Step II- To Check literature about Panchakarma Therapies can improves Bala (Immunity), as well as its immunomodulation enhancing property of Rasayana (Rejuvenation) medicines. With keen evaluation of Classical Ayurvedic texts, electronically published and Indexed scientific Journals and printed peer reviewed research articles literary review is conducted, and finally report will be prepared an interpretation and synthesis of outcome.

\section{Review Of Covid-19 And Janapadodhansa Vyadhi (Epidemic)}

Corona virus is transmitted from human to human in a chain, symptomatic patient is the most source of spreading infection of COVID-19. Due to the possibility of transmission before symptoms, the individuals who remain asymptomatic could transmit the virus, thus isolation is the best way to control this epidemic. Other symptoms are flu, and rhinovirus, it may be transmitting through respiratory droplets particle size is less than 5 to 10 micrometers, from coughing and sneezing. Incubation period is generally within 3 to 5 days and 2 weeks considered longest. Contamination occur in floors, computer mice, and patient's bed, handrails of staircase, door etc. also in air up to 4 meters from patient ${ }^{2}$. Causes of Janapadodhansa Vyadhi (Epidemic) mentioned in Ayurveda are, however without unnatural season, there is possibility of death of people because of: Abhishap (Malediction, Blight) or Kritya (magic), Anger of Rakshasadi (Demons), or production of disease due to air pollution, or Visha (Virus) ${ }^{3}$, or Aushdha (Medicines), or Pushpagandha (Smell of flowers), being spread in the region ${ }^{4}$. Vayu (Air), Jala (Water), Desha (Region), and Kala (Season) are vitiated due to unnatural seasons, Shastra Prabhav (Fighting by weapons), Rakshogana (Organism, virus), Vividha Bhuta Sanghata (various groups of ghost), Abhishapa (malediction, blight) ${ }^{5}$ Rains in Hemanta Rutu (pre-winter) considered to be unnatural thing, Suryasantapa (Sunrays) perceived during Sharad Rutu (autumn) can produce Pittaprakopa (exaggerated Pitta $)^{6}$ Symptomatology of COVID-19 described as follows: Fever, malaise, dry cough, and dyspnea. This may be present with mild, moderate, or severe illness. 
Asymptomatic or Pauci-symptomatic, Mild disease: like non-pneumonia and mild pneumonia, Severe disease: dyspnea, respiratory frequency is greater than or equal $30 / \mathrm{min} . \mathrm{SpO} 2$ is less than or equal $93 \%$, $\mathrm{PaO} 2 / \mathrm{FiO} 2$ ratio or $\mathrm{P} / \mathrm{F}$ and the percentage of oxygen supplied is less than 300 , and /or lung infiltrates less than $50 \%$ within 24 to 48 hours. Critical disease: respiratory failure, septic shock, and/or multiple organ dysfunction (MOD) or failure (MOF) ${ }^{7}$ Symptoms of Janapadodhansa Vyadhi (Epidemic) in Ayurveda described as: At any given time, people suffer with same symptoms of a single disease ${ }^{8}$. Amongst them some common symptoms are Kasa (Cough), Shwasa (Dyspnea), Vamathu (Vomiting), Pratishaya (Common cold), Shirorug (Headache) and Jwara (Fever) ${ }^{9}$. Batalika Pitka (Watery blisters) present on the body parts like Kakshaya (Upper and lower extremities), Urumula (Origin of the thigh), Tala of Pani and Pada (Palm and sole), Kantha (Throat), Shrotram (Ear), Vasti (Bladder) and Hrudaya (Heart) ${ }^{10}$. Pathology of Janapadodhansa Vyadhi (Epidemic) described in Ayurveda as per following: At a time people suffered from symptoms of a single disease i.e. Janapadodhansa Vyadhi (Epidemic) even if they have different Prakruti (Constitution), Ahara (Diet), Deha (Body), Bala (Power), Satmya (Addiction), Mana (Mind), and Ayu (Age). This happens because of Vikriti (Vitiation) in Samanya Bhava (General causative factors) like Vayu (Air), Jala (Water), Desha (Region), Kala (Season). And because of Unnatural Nakshtra (Stars), Grahagana (Planet), Chandra (Moon), Surya (Sun), Vayu (Wind), Agni (Fire), and Disha (Side), etc. as well as unnatural Rutu (Seasons) affects immediately on properties of the medicines that gets destroyed ${ }^{11}$. When patient have severe symptoms then deaths occurs in population so Janapadodhansa disease is also called as Janamar. Mostly it is a Pitta and Shleshma Pradhan disease, associated with Vatashonita $^{12}$. Contamination spreading through: house, bed and sitting site, vehicle, Mani (Gem), Ratna (Stone), and other contaminated utensils ${ }^{13}$. Vayu (Air), Jala (Water), Desha (Region), Kala (Season), Chitraka (Plumbago Zeylanica), Dhanyeshu (Rice, grains etc.), Moolaphaleshu (Ground roots and fruits)
Humans can also suffer from the said $V y a d h i^{14}$. Treatment of Janapadodhansa Vyadhi (Epidemic) stated in Ayurveda as: Sthanapridyaga (Shifting residence), treating the said disease we should use uncontaminated medicines and water. For Kalyana (Fortunate), it is advised to collect the medicines before Bhumi (Soil) gets vitiated due to unnatural Rutu (Season), and prepare good quality medicines, such medicines should be used in the patients; considering Ayurvedic properties like Rasa, Virya, Vipaka and Prabhava. Good quality medicines can cure the epidemic without any difficulty. Panchakarma are more useful for patients who suffer from such diseases, that they find procedures and death on similar level ${ }^{15}$. Panchakarma namely Vamana (Emesis), Virechana (Purgation), Basti (Medicated enema), Nasya (Errhine), Raktamokshana (Bloodletting) and Rasayana treatments are most beneficial when administered as per protocol $^{16}$

\section{Panchakarma Therapies Have Bala (Immun- ity) Enhancing Potential}

Vigor of seven Dhatus (Rasa to Shukra) is known as Oja; and Bala (Immunity) is another name of Oja (Vigor) ${ }^{17}$. Bhahudosh Awastha Laxana-Balanash (immunocompromised state) is mentioned in symptoms of Bahudoshavastha in which Panchakarka therapy are especially indicated ${ }^{18}$. Panchakarma therapies increase Bala (Immunity) as mentioned in its benefits of performing Panchakarma therapies ${ }^{19}$. Laxanas of Prakrutistha Purusha (Signs of normal human health) occurs when cleansing is done through Panchakarma therapies ${ }^{20}$.

\section{Understanding Concept Of Mala (Root Causes) With Present Perspective}

There are two types of body Dhatus, one is Malabhuta and another is Prasadbhuta, out of these Malabhuta Dhatus can produces difficulties in the body, therefore they are known as Sharirasya Badhakaraha (Harmful elements) of the body, elements that stick to Srotas (eg. $A m a$, undigested food constituents, saturated cholesterol, etc.), differently produced and excreted Malas from the eyes, ears, nose, etc. ripened Dhatu means Vranotpattijanya Puya (Ulcerative pus) of Rasa (Plasma), Rakta (Blood), Mansa (Muscle), Meda (Vasa 
excreted from Mansa), Asthi (Bone), Majja (Bonemarrow), Shukra (Semen), decreased or exaggerated Vata, Pitta and Kapha Doshas, (Vata means Eerana that fills the gaps and the minute and large pores of the body. Pitta means Fluids like gastric juices used for digestion and nutrition, pancreatic juice and blood or much of the substances latent in these fluids are included in Pitta Dosha. Kapha denotes all fluids and solid parts of the body like saliva, lymph, plasma, fat, mucus membranes, and mucus when they are at their proper places are called as Kapha Dosha) ${ }^{21}$. Kapha denotes mucus in terms of mucopolysaccharides ${ }^{22}$. Any other body constitute produced eg. endocrinal, allergic conditions etc. and also, Androgen, T-cells, and Thyroxine are related to Pitta (mesomorphic or andrus), Kapha (endomorphic or thymus), and Vata (ectomorphic or thyrus), respectively $^{23}$, thus all these can be harmful to immune system, or produce disease in the body, therefore they are called as 'Mala' ${ }^{24}$.

\section{Shodhana (Cleansing) Gives Booster To Im- munmodulators Like Rasayana (Rejuvenation)}

Cleansing of Mala present in the body by administrating Panchakarma therapies is essential before $R a$ sayana (Rejuvenation) medicines like Brahmarasayan, Amalak rasayan, Chawanprash rasayan and Vajikarna (Aphrodisiac) medicines like Madhuyashti yoga, Amalak yoga, Vidaryadi yoga otherwise it does not produce desired immunomomodulatory effect, just like painting on a dirty $\operatorname{cloth}^{25}$. Koshtha means Mahasrotas (Alimentary canal ${ }^{26}$, Koshtha includes the organs Amashaya (Stomach), Agnyashaya (Pancreas), Pakashaya (Intestine), Mootrashaya (Kidneys \& Bladder), Rudhirashaya (Liver \& Spleen), Hrudaya (Heart), Unduk (Caecum) and Phuphus (Lungs) ${ }^{27}$. Cleansing of Mala present in all above organs is achieved by administering Panchakarma therapies which further gives booster to immunmodulators like Rasayana (Rejuvenation) and Vajikarna (Aphrodisiac) medicines. Srotas in the body are Pranavaha (Air channels) Udakavaha (Water channels) ,Annavaha (Food channels), Rasavaha (Essence channel), Raktavaha (Blood channels), Mansavaha (Muscle channels), Medovaha (Fat channels), Asthivaha (Bone and cartilage channels),
Majjavaha (Bone marrow channels), Shukravaha (Ovum and sperm channels), Mootravaha (Urinary channels), Purishavaha (Excretory channels), Svedavaha (Sweat channels) ${ }^{28}$, Artavavaha (Menstrual channels) ${ }^{29}$. Cleansing of Mala present in all above Srotas (Channels) is done by administering Panchakarma therapies which is prerequisite for Vajikarana (Aphrodisiac) medicines and improved sexual power and Balapradam (Immunomodulation). Rasayana promotes nutrition by explicitly enriching the nutritional value of Rasa by enhancing Agni, i.e. digestion, metabolism, and absorption (by Srotoshodhana). Consequently, any medication that improves Rasa's consistency would enhance the health of all body tissues. ${ }^{30}$

\section{DISCUSSIONS}

Both diseases are identical in nature, Janapadodhansa is epidemic, COVID-19 is also epidemic, declared by WHO. Virus is very prominent cause of both disease. Janapadodhansa Vyadhi caused due to Visha (Virus), and disease COVID-19 caused due to Corona Virus $(\mathrm{CoV})$. Infection of Visha (Virus) and $\mathrm{CoV}$ transmitted by droplet of coughing and sneezing. Both disease having similar signs and symptoms, Janapadodhansa Vyadhi have Laxanas (Symptoms) like Kasa (Cough), Shwasa (Dyspnea), Vamathu (Vomiting), Pratishaya (Common cold), Shirorug (Headache), Jwara (Fever) and Batalika Pitka (Watery blisters), disease COVID19 have signs and symptoms like fever, malaise, dry cough, and dyspnea. Contamination occurred in utensils, Vayu (Air), Jala (Water), Desha (Region), Kala (Season), medicines and food items etc., are mentioned in Janapadodhansa Vyadhi (Epidemic). And floors, computer mice, trash cans, and sickbed, handrails as well as in air up to 4 meters from patients etc., are mentioned in disease COVID-19. Anyone can get infected from this disease, in Janapadodhansa Vyadhi (Epidemic) it has been mentioned that, at a time people having different Prakruti (constitution), Ahara (Diet), Deha (Body), Bala (Power), Satmya (Addiction), Mana (Mind), and $A y u$ (Age), suffer from a single type of disease. The same is observed in disease COVID-19, that anyone can get infected, those who come to close with the patient. In the treatments of both disease it has been 
mentioned that quarantine of the patient is necessary to avoid further spreading. Panchakarma procedures are more beneficial for patients who suffer from such kind of diseases, that they find procedures and death on similar level. We observed above similarities between COVID-19 and Janapadodhansa Vyadhi (Epidemic). Therefore, we can consider Symptomology, Treatment protocol etc. of Janapadodhansa Vyadhi (Epidemic) mentioned in Ayurveda for prevention and management of COVID-19. Panchakarma therapies have potency to improve Oja (Vigor) and Bala (Immunity), cure Balanasha (immunocompromised state) and acquiring of Prakruti Purusha Laxana (Signs of normal human health), considering this fact we can advocate Panchakarma therapy individually to improve Bala (Immunity) in patients of COVID-19. In preoperative measures, Snehana (Oleation) and Swedana (Sudation) procedures are done to well prepare Mala (Root causes) to come out easily from logged places, and then expelled out from the body by Shodhana (cleansing) potency of Panchakarma Therapies. Because of detoxification of all organs including Koshtha, Srotas and whole body, Agni Vyapara (Metabolism) gets enhanced, pre-existing diseases get cured, Body homeostasis is obtained and ultimately Bala (Immunity) gets improved at this state body is ready for regeneration and this regeneration is achieved by Rasayana (Rejuvenation) and Vajikarna (Aphoristic) medicines which again possess immunomodulation potency. With this fact we can advocate Panchakarma therapies to improve immunomodulation potency of Rasayana (Rejuvenation) medicines in patients of COVID-19. With the above discussion we can conclude that Prayojan (Aim) of Ayurveda i.e. to prevent from disease and maintain health of desired and to cure agony of the persons can be achieved by Panchakarma therapies in current scenario of COVID 19 pandemic.

\section{CONCLUSIONS}

We observed that, Janapadodhansa Vyadi (Epidemic) and disease COVID-19 are very similar. Panchakarma therapies independently bears immunity enhancing potency and it acts as immunomodulator when used prior to Rasayana (Rejuvenation). Panchakarma therapies can be administered independently and as a preoperative measure of Rasayana following work place guidelines in the healthy individuals and in asymptomatic or mild symptomatic patients of COVID-19.

\section{REFERENCES}

1. Bhargava B, Online news paper-Times of India. One in 15 people exposed to Covid-19 by August: ICMR second sero survey, https://timesofindia.indiatimes.com/india/one-in-15-people-aged-10-andabove-estimated-to-be-exposed-to-covid-19-by-augusticmr-sero-survey/articleshow/78386860.cms (Sept 30, 2020)

2. Cascella M, Rajnik M, Cuomo A, et al. Features, Evaluation and Treatment Coronavirus (COVID-19), In:Stat Pearls. Treasure Island (FL): Stat Pearls Publishing, (August 10 2020).(www.ncbi.nlm.nih.gov/books/NBAK554776)

3. Sharma A, ed. Sushrita Samhita Volume I. Varanasi, India: Choukhamba Surbharati Prakashana, 2004:53

4. Sharma A, ed. Sushrita Samhita Volume I. Varanasi, India: Choukhamba Surbharati Prakashana, 2004:53

5. Shastri K, Chaturevedi G, ed. Charak Samhita Part-I. Varanasi, India: Choukhamba Bharati Academy, 1993:692,693,694

6. Hornle, ed. The Bhela Samhita, Culcutta, India: The University of Culcutta, 1921:22,23

7. Cascella M, Rajnik M, Cuomo A, et al. Features, Evaluation and Treatment Coronavirus (COVID-19), In:Stat Pearls. Treasure Island (FL): Stat Pearls Publishing, (August 10 , 2020).(www.ncbi.nlm.nih.gov/books/NBAK554776)

8. Shastri K, Chaturevedi G, ed. Charak Samhita Part-I Varanasi, India: Choukhamba Bharati Academy, 1993:692

9. Sharma A, ed. Sushrita Samhita Volume I. Varanasi, India: Choukhamba Surbharati Prakashana, 2004:53

10. Hornle, ed. The Bhela Samhita, Culcutta, India: The University of Culcutta, 1921:23

11. Shastri K, Chaturevedi G, ed. Charak Samhita Part-I. Varanasi, India: Choukhamba Bharati Academy, 1993:692

12. Hornle, ed. The Bhela Samhita, Culcutta, India: The University of Culcutta, 1921:23

13. Sharma A, ed. Sushrita Samhita Volume I. Varanasi, India: Choukhamba Surbharati Prakashana, 2004:53

14. Hornle, ed. The Bhela Samhita, Culcutta, India: The University of Culcutta, 1921:23 
15. Shastri K, Chaturevedi G, ed. Charak Samhita Part-I. Varanasi, India: Choukhamba Bharati Academy, 1993:694

16. Shastri K, Chaturevedi G, ed. Charak Samhita Part-I. Varanasi, India: Choukhamba Bharati Academy, 1993:694

17. Sharma A, ed. Sushrita Samhita Volume I. Varanasi, India: Choukhamba Surbharati Prakashana, 2004:124

18. Shastri K, Chaturevedi G, ed. Charak Samhita Part-I. Varanasi, India: Choukhamba Bharati Academy, 1993:320-321

19. Shastri K, Chaturevedi G, ed. Charak Samhita Part-I. Varanasi, India: Choukhamba Bharati Academy, 1993:321

20. Shastri K, Chaturevedi G, ed. Charak Samhita Part-II. Varanasi, India: Choukhamba Bharati Academy, 1995:1092

21. Varier PS, Chikitsa Samgraham, Kottakkal, India: Arya Vaidya Sala, 2004:xxiv

22. Singh RH, Pancakarma Therapy, Varanasi, India: Choukhambha Sanskrit Series office, 1992:257

23. Dey S, Pahwa P. Prakriti and its associations with metabolism, chronic diseases, and genotypes. J Ayurveda Integr M 2014; 5(1):15-24

24. Shastri K, Chaturevedi G, ed. Charak Samhita Part-I. Varanasi, India: Choukhamba Bharati Academy, 1993:902

25. Tripathi B, ed. Ashtanga Hridayam, Delhi, India: Choukhamba Sanskrita Pratishthana, 2011:1183,1187, 1208, 1209.

26. Shastri K, Chaturevedi G, ed. Charak Samhita Part-I. Varanasi, India: Choukhamba Bharati Academy, 1993:235

27. Sharma A, ed. Sushrita Samhita Volume II. Varanasi, India: Choukhamba Surbharati Prakashana, 2004:176

28. Shastri K, Chaturevedi G, ed. Charak Samhita Part-I. Varanasi, India: Choukhamba Bharati Academy, 1993:692

29. Sharma A, ed. Sushrita Samhita Volume II. Varanasi, India: Choukhamba Surbharati Prakashana, 2004:122

30. Gautam $\mathrm{S}$, et al. Immunity against COVID-19: Potential role of Ayush Kwath. J Ayurveda Integr Med. https://doi.org/10.1016/j.jaim.2020.08.003

\section{Source of Support: Nil}

\section{Conflict of Interest: None Declared}

How to cite this URL: Vedpathak $\mathrm{S}$ et al: A Review Of Panchakarma Therapies With Respect To Bala (Immunity) For Prevention And Management Of Covid-19. International Ayurvedic Medical Journal \{online\} 2020 \{cited November, $2020\}$ Available from: 